\title{
Using the ADDIE Model in the Development of Physics Unit Conversion Application Based on Android as Learning Media
}

\author{
Nurfidah Dwitiyanti (*), Siti Ayu Kumala, Fita Widiyatun \\ Department of Informatics, Faculty of Engineering and Computer Science, Universitas \\ Indraprasta PGRI, South Jakarta, DKI Jakarta 12530, Indonesia
}

Received: February 26, 2020

Revised: April 29, 2020

Accepted: June 24, 2020

\begin{abstract}
Physics is one of the sciences that studies concepts, laws, formulas, and also real and abstract phenomena. There are too many formulas in Physics that must be understood by students, make students feel difficult and less enthusiastic in learning Physics. One of the material that makes students like to forget is the material about unit conversions where the number of units that need to be remembered are units of length, acceleration, speed, energy and others. To solve this problem, it is necessary to make an application in the android system that can help in the conversion unit and is easily accessible. The method used in this research is Research and Development $(\mathrm{R} \& D)$ using ADDIE Model. Several procedures employed in ADDIE Model cycle, they are: (1) Analysis, (2) Design, (3) Development, (4) Implementation and (5) Evaluation that will be developed in this application. The results of the feasibility test from material experts are based on three aspects of assessment, namely the aspect of language, the suitability of concepts and the illustrations, of which the feasible category releases in a total percentage of eligibility of $79,76 \%$. Meanwhile, based on the results of the media expert, feasibility tests are based on three aspects of assessment, namely graphics, program processing and usage that are in the very feasible category with a total percentage of eligibility of $88,89 \%$.
\end{abstract}

Keywords: Unit-Conversion, Physics Learning, ADDIE Model

(*) Corresponding Author: $\quad$ Nurfidah.pulungan@gmail.com, 081382449934.

How to Cite: Dwitiyanti, N., et al. (2020). Using the ADDIE model in the development of physics unit conversion application based on android as learning media. Formatif: Jurnal Ilmiah Pendidikan MIPA, 10 (2): 125-132. http://dx.doi.org/10.30998/formatif.v10i2.5933

\section{INTRODUCTION}

Physics is a science that studies concepts, laws, formulas, real and abstract phenomena (Gagese, Wahyono and Kendek, 2018). There are too many formulas in Physics that must be understood by students, making students feel difficult and are less enthusiastic in studying Physics. One of difficult materials to memorize is a unit conversion in which the number of physical units that need to be remembered includes units of length, acceleration, velocity, energy and others.

This problem can be overcome by paying attention to one of the components in the learning system, namely the use of learning media. However, in many schools, teachers are not interested in creating and developing learning media. Teachers only use conventional learning methods in delivering material without using learning media while learning media can increase student's interest in learning (Astuti et al., 2019). Learning media play an important role in encouraging the smoothness of the teaching and learning process. To simplify the students, convert Physics units, a learning media is needed. 
The ADDIE model is a model commonly used in developing instructional design, but can substantially be used in the development of instructional media (Zahid, 2018). An approach using this model can help design learning systems, develop learning content or teachers to make efficient and effective teaching designs by applying the ADDIE model process to various learning products (Aldoobie, 2015).

The use of the Android operating system in smartphones covers all fields, from the social, economic and even education fields. The massive use of android in everyday life can be used by teachers to develop learning supported by smart phones or experts based on android (Zahid, 2018). Android-based application is expected to simplify the students in receiving and understanding learning material, on the other hand, it also simplifies the teachers to deliver learning material. Research on android for educational activities has been widely carried out. The example is research on the use of android applications in Mathematics learning for curved side space building materials at SMPN 1 Sragen (Sri Mulyani, 2018). In addition, research has also been conducted on the design of Androidbased static and dynamic electricity learning media (Zaus, et. al., 2018).

The use of the ADDIE model in android-based product development for learning has been well-known. Sa'adah, et. al., (Sa'dah and Arianti, 2019) use the ADDIE model as one of the developments of an Android-based TOEFL test simulation application at FKIP Hamzanwadi University. The ADDIE model is also used for the development of the "Science Learning Channel" portal as an online learning video (M.sc, 2016) and other multimedia-based learning applications (Sukenda, Falahah and Lathanio, 2013), (Stapa and Mohammad, 2019). In this study, the ADDIE model is used for the development of an Android-based Physics unit conversion application.

This is based on the results of observations on first-year students in the campus environment of Indraprasta University PGRI Jakarta through the distribution of questionnaires. It was found that there were some students who had difficulty converting Physics units manually, without using tools in the form of conversion application unit as a learning media. Hence, the researchers are interested in developing an Android-based physics unit conversion media by using the ADDIE model. This Android-based Physics unit conversion application can be as a learning media for students in solving unit conversion problems of basic Physics course.

\section{METHODS}

The method used in this research was Research and development. Research and development are a research method used to produce certain products and to test the effectiveness of these products. Meanwhile, according to Sugiyono (2011: 297), Research and Development is a research method producing certain products and testing the effectiveness of these products. The product produced from this research is a learning media in the form of an Android-based Physics unit conversion application.

Meanwhile, the development model of the Physics unit conversion application based on android used the ADDIE model design model. The ADDIE model has a focus or emphasis on iteration and reflection, so that continuous improvement can be made that focuses on feedback (Harjanta and Herlambang, 2018). The ADDIE model has 5 stages, including Analysis, Design, Development, Implementation and Evaluation. (Widyastuti and Susiana, 2019). Visually, the stages in the ADDIE model can be seen in Figure 1. 


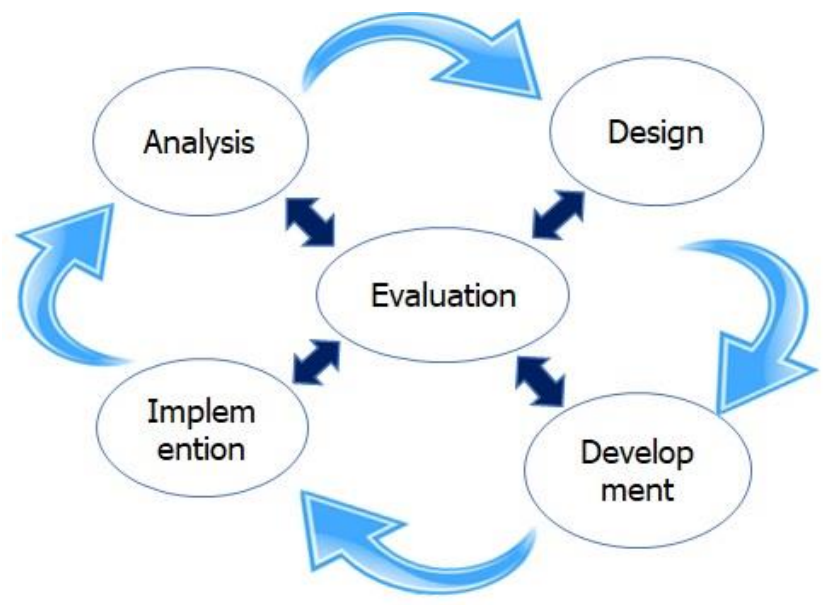

Figure 1. ADDIE Model

The initial stage was the analysis stage and literature study. At this stage, a preliminary survey was conducted to find out what students needed in the unit of conversion learning in motion Physics/basic Physics courses. The needs analysis includes what materials and media were needed and what was not currently available. After obtaining the material to make learning media at the analysis stage, the researchers then designed the Android-based Physics unit conversion application. At this stage, the design of content framework for the application program was determined. The program content framework was used to describe the entire content of the material included theory, conversion, problem solving example, drawing, layout, animation, background and color.

Furthermore, the Development stage was the product realization stage. At this stage, the android-based unit conversion application was developed in accordance with the design that was carried out in the previous stage, namely the analysis and design stage. Then, proceed to the next stage, the implementation stage, where at this stage product validation testing was carried out by material experts and media experts, as well as to respondents. Testing learning media was done by testing a questionnaire. Respondents in this study were 50 students in the first semester who were taking basic Physics courses. The final stage of the ADDIE model was the Evaluation stage, where in this stage it was the evaluation process of application that had been made which was adjusted to the previous stages. This evaluation was based on application trials conducted by the validator and an assessment of the feasibility of the application through distributing questionnaires. The result of this stage was the application test results report. Based on this stage, the application made was corrected if a system error was found in the application so that the application can be widely used as a learning media for basic Physics courses.

\section{RESULTS \& DISCUSSION}

\section{Results}

The following shows the results of Research and Development of an Androidbased Physics unit conversion application as a learning media in basic Physics courses. The results of developing an Android-based unit conversion application can be seen in the figure 1. 


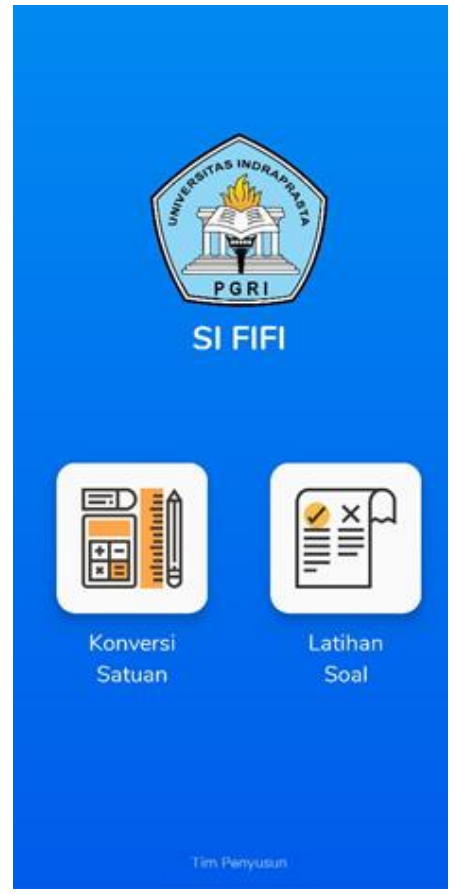

Figure 1. Main Menu Display of Android-Based Physics Unit Applications
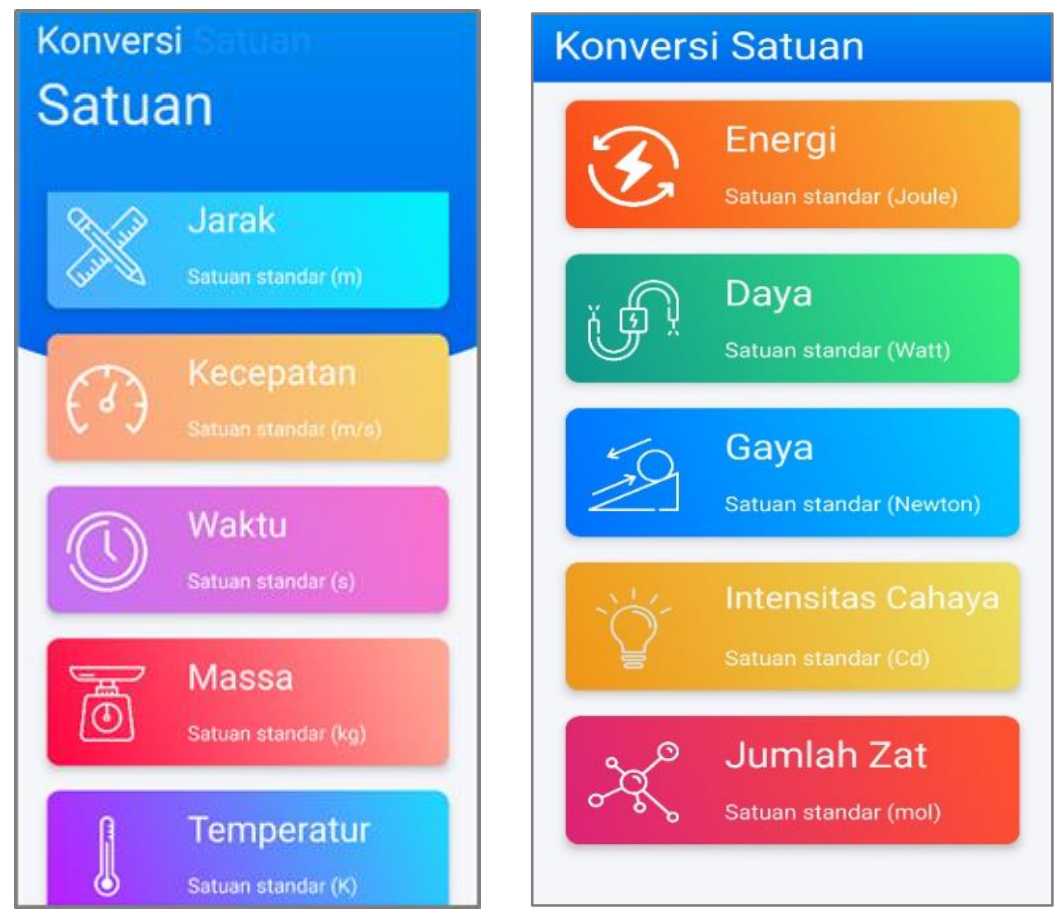

Figure 2. Menu Display of Physical Unit Conversion Options 

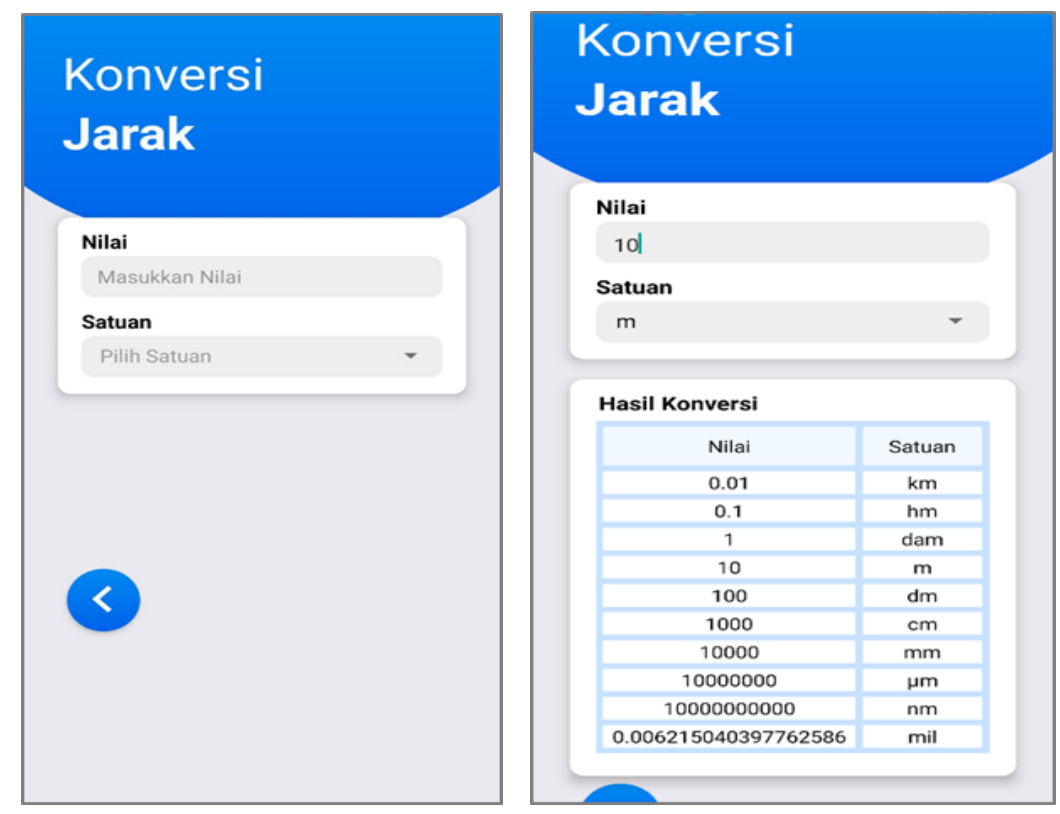

Figure 3. Display of Physical Unit Conversion

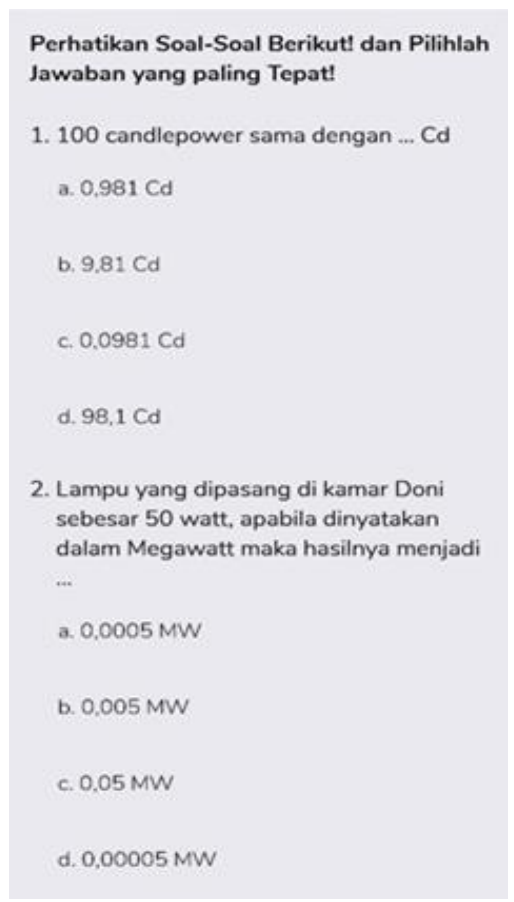

Figure 3. Display of Exercise Questions

The Android-based Physics unit conversion application has been assessed by material experts and media experts. The expert validation process involves 4 lecturers, namely 2 material expert lecturers and two media expert lecturers. Expert lecturers were selected with the following criteria: a) a minimum academic degree of Masters (S2) in Physics and Computers, b) Experienced in teaching Physics and Computing at least 3 years, and c) Experienced in research and has been a validator expert in the field of Physics and Computers. 
The assessment criteria used in this study as seen through the following table 1 (Widyawati and Prodjosantoso, 2015).

Table 1. Assessment Criteria

\begin{tabular}{cll}
\hline No & Score Range & Category \\
\hline 1 & $0 \%-20 \%$ & Very Less Feasible \\
2 & $21 \%-40 \%$ & Less feasible \\
3 & $41 \%-60 \%$ & Enough \\
4 & $61 \%-80 \%$ & Feasible \\
5 & $81 \%-100 \%$ & Very Feasible \\
\hline
\end{tabular}

by calculating the percentage of Feasibility:

$V_{i}=$ Number Per Aspect / (Max Score $\times$ Number of Validators $\times$ Number of points per aspect) $\times 100 \%$.

a) Results of Material Expert Assessment

The assessment of the material aspects in this study is carried out by two Physics lecturers using a questionnaire. The discussion in the material aspect included the concepts and contents in the learning media for the Android-based Physics unit conversion application. The questionnaire distributed to material experts consists of 3 aspects of the assessment and 13 questions. The results of the validation data by material experts are presented in table 2 as follows:

Table 2. Results of Material Expert Assessment

\begin{tabular}{cll}
\hline No & Aspect & Percentage \\
\hline 1 & Language & $83,33 \%$ \\
2 & Conformity Concepts & $89,29 \%$ \\
3 & Illustration & $66,67 \%$ \\
& Average & $\mathbf{7 9 , 7 6 \%}$ \\
\hline
\end{tabular}

b) Result of Media Expert Assessment

Assessment of the media aspect is as same as the assessment on the material aspect, which involves two lecturers then completing the assessment questionnaire sheet which consists of 3 aspects, namely the graphic aspect, the program processing aspect and the usage aspect. The sum of all statements from all aspects is 11 statements. The results of the media expert's validation are presented in table 3 .

Table 3. Result of Media Expert Assessment

\begin{tabular}{cll}
\hline No & Aspect & Percentage \\
\hline 1 & Graphic & $78,57 \%$ \\
2 & Program Processing & $93,75 \%$ \\
3 & Usage & $93,75 \%$ \\
& Average & $\mathbf{8 8 , 6 9 \%}$ \\
\hline
\end{tabular}

c) Recommendations and Suggestions of Material and Media Experts

According to the material expert validators and media experts, there are several suggestions or inputs to improve the media so that it is more suitable for use. Recommendation and suggestion from the results of validation by material and media experts are as follows:

1) In the Android-based Physics unit conversion application, it is suggested that additional instructions for using the application, learning objectives and indicators/competencies in the application are needed. 
2) In the Android-based Physics unit conversion application, it is recommended that: there is a need for additional understanding of conversion and application usability on the application dashboard. Furthermore, for the initial display, it needs to be adjusted to the type and the function of the application and for each conversion menu and conversion value column, it is necessary to add a menu selection list.

\section{Discussion}

The Android-based Physics unit conversion application developed using the ADDIE model has a main menu page. On the main menu page, there are two menu options, namely unit conversion and question practice. In the Physics conversion options display include the option of Physics units including Distance, Speed, Time Mass and other Physics units. When the user selects one of the Physics unit options available on the main menu page, the user will be directed directly to the respective Physics unit conversion material, where in each conversion displays the value and conversion result will be presented. Furthermore, in the question practice view, there are several story questions about the conversion of Physics units. This page is an evaluation of students in understanding the material conversion of Physics units.

The media feasibility test is conducted by validating the media. Media design validation is performed after initial product creation. Validation is carried out in 2 types, namely validation of material experts and validation of media experts. Product is validated and assessed by validators who are experts in their fields. Validation is carried out by providing a questionnaire of instruments that have previously been validated by the appointed lecturer. Validation sheets are given to one media expert validator and one material expert validator. To find out the feasibility of a product so that it can be used in the learning process, the product must have a Feasibility of $\geq 60 \%$.

The results of the assessment of the two material experts are then processed to determine the percentage of the feasibility score of each aspect of the learning media in the form of an Android-based Physics unit conversion application using the Likert scale formula. In the linguistic aspect, the value is $83.33 \%$, for the suitability of the concept releases $89.29 \%$ and for the illustration aspect is $66.67 \%$. Meanwhile, the average assessment for all aspects of the Physics learning media in the form of the Physics unit conversion application is $79.76 \%$.

Whereas for the results of the assessment of the two media experts, the graphical aspect obtains a value of $78.57 \%$, for the processing aspect of the program is $93.75 \%$ and for the illustration aspect is of $93.75 \%$. Meanwhile, the average assessment of these 3 aspects is $88.69 \%$. This means that the learning media for the Android-based Physics unit conversion application is in a very feasible category.

\section{CONCLUSION}

Based on the results of the analysis and discussion, it can be concluded as follows: 1) The learning media in the form of an Android-based Physics unit conversion application has been successfully developed according to the needs of the researcher, which is based on the ADDIE model and consists of 5 steps including Analysis, Design, Development, Implementation and Evaluation. 2) The Android-based Physics unit conversion application can be used as a learning media and a unit conversion application in general based on the assessment of the expert as a validator. The media expert gives a score of 88.69 in the "very feasible" category, while the material expert gives a score of 
79.76 in the "feasible" category. 3) Student responses in using the unit conversion application look positive and enthusiastic.

\section{ACKNOWLEDGEMENT}

Thanks to Universitas Indraprasta PGRI through LPPM of Universitas Indraprasta PGRI for the DIPA Unindra research grant according to research contract number 01490/SP3/KP/LPPM/UNINDRA/X/2019.

\section{REFERENCES}

Aldoobie, N. (2015). ADDIE Model. American International Journal of Contemporary Research, 5(63).

Astuti, D. P., et al. (2019). Developing Adobe Flash-based mathematics learning media for 7th-grade students of junior high school. Journal of Physics: Conference Series, 1188(1). doi: 10.1088/1742-6596/1188/1/012098.

Gagese, N., Wahyono, U., \& Kendek, Y. (2018). Pengembangan mobile learning berbasis android pada materi listrik dinamis. JPFT (Jurnal Pendidikan Fisika Tadulako Online), 6(1). doi: 10.22487/j25805924.2018.v6.i1.10018.

Harjanta, A. T. J. \& Herlambang, B. A. (2018). Rancang bangun game edukasi pemilihan gubernur Jateng berbasis android dengan model ADDIE. Jurnal Transformatika, 16(1). doi: 10.26623/transformatika.v16i1.894.

Arsini. (2016). Pengembangan portal "channel pembelajaran sains" sebagai video pembelajaran online melalui model ADDIE (Analysis, Design, Development, Implementation and Evaluation). Phenomenon: Jurnal Pendidikan MIPA, 6(1). doi: 10.21580/phen.2016.6.1.940.

Sa'dah, S. \& Arianti, B. D. D. (2019). Aplikasi simulasi tes TOEFL berbasis android di Fakultas Keguruan dan Ilmu Pendidikan Universitas Hamzanwadi. EDUMATIC: Jurnal Pendidikan Informatika, 3(1). doi: 10.29408/edumatic.v3i1.1391.

Sri Mulyani, E. W. (2018). Dampak pemanfaatan aplikasi android dalam pembelajaran bangun ruang. Kwangsan: Jurnal Teknologi Pendidikan, 6(2), 122-136. doi: 10.31800/jtp.kw.v6n2.p122--136.

Stapa, M. A. \& Mohammad, N. (2019). The use of ADDIE model for designing blended learning application at vocational colleges in Malaysia. Asia-Pacific Journal of Information Technology and Multimedia, 8(1), 49-62.

Sukenda, Falahah, \& Lathanio, F. (2013). Pengembangan aplikasi multimedia pengenalan pemanasan global dan solusinya menggunakan pendekatan ADDIE. Seminar Nasional Sistem Informasi Indonesia (SESINDO), 2, 186-190.

Widyastuti, E. \& Susiana (2019). Using the ADDIE model to develop learning material for actuarial mathematics. Journal of Physics: Conference Series, 1188(1). doi: 10.1088/1742-6596/1188/1/012052.

Widyawati, A. \& Prodjosantoso, A. K. (2015). Pengembangan media komik IPA untuk meningkatkan motivasi belajar dan karakter peserta didik SMP. Jurnal Inovasi Pendidikan IPA, 1(1). doi: 10.21831/jipi.vli1.4529.

Zahid, M. Z. (2018). Aplikasi berbasis android untuk pembelajaran: Potensi dan metode pengembangan. PRISMA. Prosiding Seminar Nasional Matematika, 1, 910-918.

Zaus, M. A. et al. (2018). Perancangan media pembelajaran listrik statis dan dinamis berbasis android. INTECOMS: Journal of Information Technology and Computer Science, 1(1), 1-7. doi: 10.31539/intecoms.v1i1.140. 